\title{
Economic Comparison of Concrete Recycling: A Case Study Approach
}

\author{
Vivian W. Y. Tam ${ }^{1 *}$
}

\begin{abstract}
Recycling of construction material helps saving the limited landfill space. Among various types of materials, concrete waste accounts for about $50 \%$ of the total waste generation. The current practice for dumping construction materials to landfills generates a significant quantity of waste from construction sites. Recycling concrete waste as recycled aggregate is one of the methods to reduce the concrete waste. Therefore, this paper investigates the economical considerations in recycling concrete waste. A comparative study on costs and benefits between the current practice and the concrete recycling method is examined. The study shows that it has a negative net benefit for the current practice while a positive net benefit for the concrete recycling method. Therefore, recycling concrete as aggregate for new concrete production can provide a cost-effective method for the construction industry and help saving the environment.
\end{abstract}

Keywords: Benefit, cost, economical, recycling, concrete, construction

\section{Introduction}

The promotion of environmental management and the mission of sustainable development worldwide have exerted the pressure for the adoption of proper methods to protect the environment across all industries including building and construction. Construction by nature is not an environment-friendly activity. The hierarchy of disposal options, categorises environmental impacts into six levels, from low to high: to reduce, reuse, recycling, compost, incinerate and landfill (Peng et al., 1997). Three main waste minimisation strategies of reuse, recycle and reduction, are

\footnotetext{
${ }^{1 *}$ Corresponding author, Griffith School of Engineering, Griffith University, PMB 50 Gold Coast Mail Centre, QLD 9726, Australia. Tel: (61) 7 -5552-9278; Fax: (61) 7-5552-8065; Email: v.tam@griffith.edu.au
} 
collectively called the "3Rs". To reduce construction waste generated on site, coordination amongst all those involved in the design and construction process is essential.

Recycling, being one of the strategies in minimizing waste, offers three benefits (Edwards, 1999, Kawano, 1995): i) reduce the demand for new resources; ii) cut down on transport and production energy costs; and iii) utilise waste which would otherwise be lost to landfill sites. Construction and demolition waste including demolished concrete, bricks and masonry, wood and other materials such as glass, insulation, roofing, wires, pipes, rocks and soil (Coventry, 1999), constitutes a significant component of the total waste. Among them, concrete waste accounts for about $50 \%$ of the total waste generation (Australian Government, 2006, Australian Government: Productivity Commission, 2006, Hendriks and Pietersen, 2000, Li, 2002, Mulheron, 1988). Regarding the huge generation of concrete waste, five major causes are identified, including (Cheung, 1993, Poon et al., 2001; , 2001, Shen and Tam, 2002, Tam and Tam, 2006): i) over ordering; ii) damage during transportation; iii) loss during installation; iv) poor workmanship; and v) change of design. Therefore, this paper explores economical consideration in recycling concrete by a cost and benefit analysis.

\section{Cost and Benefit Analysis}

To investigate the cost and benefit for concrete recycling, it has been visited three construction and demolition companies, four recycling plants and two landfills in South-Eastern Queensland, Australia. Site representatives have also been interviewed. For the current practice, construction waste is dumped in landfills and new products are produced from the rocks and supplied to the site for new concrete production. It wastes energy to dump the waste and produce new materials for the production. Therefore, concrete recycling method is proposed. The construction waste is sent to recycling plants for crushing it as aggregate for new concrete production, which can save energy for 
dumping and producing new materials. This can also bring concrete materials as a closed-loop recycling process.

Detailed cost data for the current practice and the proposed concrete recycling method have been released by the Environmental Protection Agency (Environmental Protection Agency, 2007). However, some cost data are still not available from the Agency, in-depth interview discussions with site representatives from construction and demolition companies, recycling plants and landfills are thus conducted to estimate social and environmental cost required. Detailed interviews with companies are also conducted to validate the cost data and to ensure that consistent results are drawn. Detailed cost data are shown in Table 1 and Table 2 for the current practice and the proposed concrete recycling method respectively.

$<$ Table 1>

$<$ Table 2>

It should be noted that the estimated costs given in Table 1 and Table 2 are confidential and could not be verified using different sources. The only source used to collect these cost data is from in-depth interviews with company's on-site representatives. It is also believed that this practice is very common in the field of construction industry.

Based on the interview discussions, it is also found that average construction waste generated from each site is about 115,200 tons and a recycling plant has a production capacity of about 110,000 tons per year. The expected life of the plant is estimated to be about 10 years. These information are used for the cost and benefit analysis in the below sections. 


\subsection{The Current Method}

In the current method, on-site construction waste is dumped to landfills and new products are produced from rocks and supplied on the construction site for new concrete production. Figure 1 shows the flow chart for the current method and Table 1 summarizes the cost and benefit for the current method. Details are summarized as below:

- Construction waste is the first stage to be considered in cost and benefit analysis. In this stage, construction waste is sent to landfills and hence cost incurred is in the form of landfill charge (about \$57 per ton), landfill space (about \$220 per ton), transportation cost (about $\$ 5$ per ton), air pollution (about $16.5 \%$ of landfill space charge), noise pollution (about $17.7 \%$ of landfill space charge), gas emission (about $17.4 \%$ of landfill space charge), and energy consumption (about $23 \%$ of landfill space charge).

- Stripping is the stage where rocks are cleared and leveled. Equipment such as bull dozer is required. Cost incurred in this stage including labor cost, fuel cost, and fixed overhead cost.

- Blasting is the process where blasting equipment is used and capital cost, equipment cost, working capital cost (about $15 \%$ of variable operating cost), operating cost including equipment maintenance cost, and labor cost, fuel cost and fixed overhead cost are estimated.

- Stockpiling is the stage where one labor is involved at the rate of about $\$ 18$ per hour.

- Sorting is the stage where equipment such as excavator is used and capital cost, equipment cost, working capital cost (about $15 \%$ of variable operating cost), operating cost including equipment maintenance cost, labor cost, fuel cost and fixed overhead cost are estimated.

- Crushing process includes primary crushing, magnetic separation, and secondary crushing process. It involves equipment such as primary crusher, secondary crusher and shaper. In addition, capital cost, equipment cost, working capital cost (about $15 \%$ of variable operating cost), operating cost including equipment maintenance cost, labor cost, fuel cost and fixed overhead cost are estimated. In this process, the only benefit is the maintenance cost which can be saved compared to the recycling process because there is more wear and tear of the 
equipment blades. Hence, the difference between the maintenance cost for the equipment for the current method and the concrete recycling method is the benefit gained in this stage.

- Washing, screening or air-sitting process is the stage which involves fuel and recycled water (about $\$ 0.005$ per ton) to settle down dust and all particles.

- Final product stage, where the finished products of $7 \mathrm{~mm}, 10 \mathrm{~mm}, 20 \mathrm{~mm}$ and $75 \mathrm{~mm}$ aggregate are produced and sold at the rate of about $\$ 15, \$ 25, \$ 25$, and $\$ 16$ per ton respectively.

$<$ Figure 1 $>$

\subsection{Concrete Recycling Method}

In the concrete recycling method, construction waste from the site is dumped to recycling plant and new products are produced and supplied on the construction site. Figure 2 shows the flow chart of the concrete recycling method and Table 2 summarizes the cost and benefit for the proposed concrete recycling method. Details are summarized as below:

- Construction waste is the first stage to be considered in cost and benefit analysis. In this stage, dumping charge is the only cost which is being incurred at the rate of about $\$ 25.30$ per ton. Dumping the construction waste in the recycling plant had lot of benefits in the form of landfill charge (about $\$ 57$ per ton), landfill space (about \$220 per ton), transportation cost (about $\$ 5$ per ton), air pollution (about 16.5\% of landfill space charge), noise pollution (about $17.7 \%$ of landfill space charge), gas emission (about $17.4 \%$ of landfill space charge), and energy consumption (about $23 \%$ of landfill space charge).

- Stockpiling is the stage where one labor is involved at the rate of about $\$ 18 /$ hour.

- Sorting is the stage where equipments such as pulveriser and excavator are used and capital cost, equipment cost, working capital cost (about 15\% of variable operating cost), operating cost including equipment maintenance cost, labor cost, fuel cost and fixed overhead cost are estimated. 
- Crushing process includes primary crushing, magnetic separation, and secondary crushing process. It involves equipment such as primary crusher, magnetic separator, and secondary crusher. Capital cost, equipment cost, working capital cost (about 15\% of variable operating cost), operating cost including equipment maintenance cost, labor cost, fuel cost and fixed overhead cost are estimated. In this process, steel scrap is sorted out through magnetic separation process which adds to revenue and sold at about $\$ 100$ per ton.

- Manual removal process is the stage where the removal of pieces of wood, paper and plastics which are still along with the crushed materials. For this stage, one labor is involved at the rate of about $\$ 18$ per hour.

- Washing, screening or air-sitting process is the stage which involves fuel and recycled water (about $\$ 0.005$ per ton) to settle down dust and all particles.

- Final product stage, where finished products of $7 \mathrm{~mm}, 10 \mathrm{~mm}, 20 \mathrm{~mm}$ and $75 \mathrm{~mm}$ aggregate are produced and sold at the rate of about $\$ 14.8, \$ 20, \$ 22$, and 15.4 per ton respectively. As these products are sold at a lower price compared to natural products in the market, it has a profit of about $\$ 45000, \$ 200000, \$ 3600$, and $\$ 33400$ per year for $7 \mathrm{~mm}, 10 \mathrm{~mm}, 20 \mathrm{~mm}$ and $75 \mathrm{~mm}$ aggregate respectively. At this stage, the benefit gained is the difference between the price of the same quantity produced by this method and the current method.

$<$ Figure $2>$

\subsection{Comparison}

Table 3 compares the results of the cost and benefit analysis of the current method and the concrete recycling method. It should be highlighted that the concrete recycling method is more beneficial than the current method. The concrete recycling method receives a positive net benefit of about $\$ 30,916,000$ per year while the current method receives a negative net benefit of about $-\$ 44,076,000$ per year. 
There is no doubt that aggregate produced by the recycling methods is more economical in long-term than using natural materials. But, one of the factors affecting the viability of aggregate recyclers is the availability of feed materials. If construction debris or other sources of feed are not consistently available or if there is some seasonality to the availability of local feed materials that limits the recycler ability to operate at or near capacity, this can dramatically reduce operational profitability. The amount of material available for recycling is limited by sizes and changing conditions of the "urban deposit." Recycled material suppliers fail to meet demand for aggregate, so natural material production continues to be the primary source of aggregate in road construction in applications where they can substitute. At best, the contribution of recycled material will gradually grow until all available supply is consumed. Product pricing is often controlled by factors outside the direct control of the recyclers. The amount of material presently available from natural resources overshadows the amount of material available from recycling.

Product quality and uniformity can also pose a risk to the potential recyclers. Natural material producers continue to supply bulk materials for buildings and road construction because they are able to supply sufficient high quality materials for a wide variety of high-grade applications. Unless the recyclers have established long-term contracts for consistent and high-quality feed material, it may be difficult for the recycler to maintain a predictable revenue stream because of uncertainty related to future feed availability and quality or market price fluctuations. Due to the above mentioned reasons, it affects the use of recycled materials in the industry.

\section{Recommendations}

After information collected from the survey on concrete recycling situation, it is determined that there are several measures to improve the current concrete recycling situations.

a) There should has a standard specification to encourage the implementation of recycled materials for non-structural and structural applications. For example, "Guidance on the 
preparation of non-structural concrete made from recycled concrete aggregate", "Recycled aggregate applications as subgrade and pavement" and "Guide for specification of recycled concrete aggregate for concrete production (H155-2002)" from Commonwealth Scientific and Industrial Research Organization (Commonwealth Scientific and Industrial Research Organization, 1998; , 2002; , 2006).

b) One of the main burdens on the use of recycled materials is its low quality. Although there are literatures that to support high quality of recycled materials can be produced, the industry is still hesitated to use the recycled materials for new material production. It is encouraged that the government should widely initiated the use of recycled materials for their projects, which can then encourage its use to the industry.

c) It should be highlighted that improving technology for producing recycled materials can significantly improve their quality. From that, the government and clients should provide funds and incentive schemes to support the development of technologies.

d) Lack of in-house training on concrete recycling is another major issue affecting the use of recycled materials in the industry. It is encouraged that training programmes should be produced to all employees to enhance their environmental awareness, thus to improve the environment.

\section{Conclusion}

The huge generation of construction waste has reached a state that a warning signal is flicking as reflected from the running out of landfill areas. One of the best ways to manage this acute environmental problem is by recycling construction waste. As concrete waste forms the major source of construction solid waste, which contributes to about $50 \%$ of the total construction waste, recycling concrete waste is the best option to mitigate quantities of construction waste. This paper studied the cost and benefit on the current practice in dumping the construction waste to landfills and producing new natural materials for new concrete production, and the proposed concrete 
recycling method to recycle the construction waste as aggregate for new concrete production. With the advent of the cost on the current practice, it is found that the concrete recycling method can result in a huge sum of saving. The benefits gained from the concrete recycling method can balance the cost expended for the current practice. Therefore, recycling concrete waste for new production is a cost-effective method that also helps protecting the environment and achieves construction sustainability.

\section{Acknowledgement}

The author would like to thank Mr N. Patil for conducting the survey. The author is also grateful to the anonymous reviewers for constructive comment which improved the paper.

\section{References}

Australian Government, 2006. Waste and recycling in Australia. Department of Environment and Heritage, Canberra, Australian Government.

Australian Government: Productivity Commission, 2006. Waste management: productivity commission draft report. Productivity Commission, Canberra, Australian Government.

Cheung, C.M., 1993. Guidelines for reduction of construction waste on building sites. Faculty of Construction and Land use, Department of Building and Real Estate, The Hong Kong Polytechnic University.

Commonwealth Scientific and Industrial Research Organization, 1998. Guidance on the preparation of non-structural concrete made from recycled concrete aggregate. Commonwealth Scientific and Industrial Research Organization, Australia.

Commonwealth Scientific and Industrial Research Organization, 2002. Guide for specification of recycled concrete aggregate for concrete production (H155-2002). Commonwealth Scientific and Industrial Research Organization, Australia. 
Commonwealth Scientific and Industrial Research Organization, 2006. Recycled aggregate applications as subgrade and pavement. Commonwealth Scientific and Industrial Research Organization, Australia.

Coventry, S., 1999. The reclaimed and recycled construction materials handbook. London: Construction Industry Research and Information Association.

Edwards, B., 1999. Sustainable architecture: European directives and building design. Oxford: Architectural Press.

Environmental Protection Agency, 2007. Construction and demolition waste, waste management and resource use opportunities, From Queensland Government, https://www.epa.qld.gov.au/publications?id=484 (Mar, 9, 2007).

Hendriks, C.F. and Pietersen, H.S., 2000. Sustainable raw materials: construction and demolition waste. RILEM Publication.

Kawano, H., 1995. The state of reuse of demolished concrete in Japan, Integrated design and environmental issues in concrete technology : proceedings of the International Workshop 'Rational Design of Concrete Structures under Severe Conditions' Hakodate, Japan, 7-9 August 1995, 243-249.

Li, W., 2002. Composition analysis of construction and demolition waste and enhancing waste reduction and recycling in construction industry in Hong Kong. Department of Building and Real Estate, The Hong Kong Polytechnic University, Hong Kong, China.

Mulheron, M., 1988. The recycling of demolition debris, current practice, products and standards in the United Kingdom. Demolition and reuse of concrete and masonry, reuse of demolition waste, Chapman and Hall, London, 510-519.

Peng, C.L., Scorpio, D.E. and Kibert, C.J., 1997. Strategies for successful construction and demolition waste recycling operations. Journal of Construction Management and Economics, $15(1) ; 49-58$. 
Poon, C.S., Yu, T.W. and Ng, L.H., 2001. A guide for managing and minimizing building and demolition waste. The Hong Kong Polytechnic University.

Poon, C.S., Yu, T.W. and Ng, L.H., 2001. On-site sorting of construction and demolition waste in Hong Kong. Resources, Conservation and Recycling 32157-172.

Shen, L.Y. and Tam, W.Y.V., 2002. Implementing of environmental management in the Hong Kong construction industry. International Journal of Project Management, 20(7); 535-543.

Tam, W.Y.V. and Tam, C.M., 2006. Evaluations of existing waste recycling methods: a Hong Kong study. Building and Environment, 41(12); 1649-1660. 
Table 1: Cost and benefit analysis for the current method

\begin{tabular}{|c|c|c|c|}
\hline & $\begin{array}{c}\text { Cost } \\
(\$ 1,000 / y r)\end{array}$ & $\begin{array}{c}\text { Benefits } \\
(\$ 1,000 / y r)\end{array}$ & Note* \\
\hline \multicolumn{4}{|l|}{ Construction waste } \\
\hline Landfill dumping charge & $6566.4^{2}$ & & ${ }^{2}$ About $\$ 57$ per ton \\
\hline $\begin{array}{l}\text { Landfill space saved by not dumping } \\
\text { waste }\end{array}$ & $18777.6^{1}$ & & ${ }^{1}$ About $(\$ 220-\$ 57)$ per ton \\
\hline Transportation & $576.0^{3}$ & & ${ }^{3}$ About $\$ 5$ per ton \\
\hline Air pollution & $3136.3^{4}$ & & ${ }^{4}$ About $16.5 \%$ of landfill space charge \\
\hline Gas emission & $3267.3^{5}$ & & ${ }^{5}$ About $17.4 \%$ of landfill space charge \\
\hline Energy consumption & $4318.9^{6}$ & & ${ }^{6}$ About $23 \%$ of landfill space charge \\
\hline Noise pollution & $3323.6^{7}$ & & ${ }^{7}$ About $17.7 \%$ of landfill space charge \\
\hline \multicolumn{4}{|l|}{ Stripping } \\
\hline Equipment t & $145.0^{8}$ & & ${ }^{8}$ Bull dozer equipment cost is about $\$ 1,450,000$ \\
\hline Labor & $45.8^{9}$ & & ${ }^{9} 1$ person at about $\$ 45,760$ per person per year \\
\hline Fuel & 17.2 & & \\
\hline Fixed overhead & 40.6 & & \\
\hline \multicolumn{4}{|l|}{ Blasting } \\
\hline Capital & $137.8^{10}$ & & ${ }^{10}$ Blasting equipment cost is about $\$ 1,378,000$ \\
\hline Working capital & $19.4^{11}$ & & $\begin{array}{l}11 \text { 15\% variable operating cost of } \\
\text { about } \$ 19390 \text { per uni per /year (pulveriser equipment) }\end{array}$ \\
\hline Equipment maintenance & 30.1 & & \\
\hline Labor & $124.8^{12}$ & & ${ }^{12} 2$ people at about $\$ 45,760$ per person per year \\
\hline Fuel & 15.9 & & \\
\hline Fixed overhead & 40.6 & & \\
\hline Stockpiling & $37.4^{13}$ & & ${ }^{13} 1$ person at about $\$ 37,550$ per person per year \\
\hline \multicolumn{4}{|l|}{ Sorting Process } \\
\hline Capital & $168.4^{14}$ & & ${ }^{14}$ Excavator equipment cost is about $\$ 1,684,000$ \\
\hline Working capital & $19.4^{15}$ & & $\begin{array}{l}1515 \% \text { variable operating cost) of } \\
\text { about } \$ 19350 \text { per unit per year (excavator equipment) }\end{array}$ \\
\hline Equipment maintenance & 35.2 & & \\
\hline Labor & $45.8^{16}$ & & ${ }^{16} 1$ person at about $\$ 45,760$ per person per year \\
\hline Fuel & 7.8 & & \\
\hline Fixed overhead & 40.6 & & \\
\hline \multicolumn{4}{|l|}{ Crushing process } \\
\hline \multicolumn{4}{|l|}{ Primary crushing } \\
\hline Equipment & $165.1^{17}$ & & ${ }^{17}$ Primary crusher equipment cost is about $\$ 1,651,000$ \\
\hline Working capital & $18.9^{18}$ & & $\begin{array}{l}1815 \% \text { of variable operating cost of } \\
\text { about } \$ 18,930 \text { per unit per year (primary crusher) }\end{array}$ \\
\hline Equipment maintenance & 30.1 & $10.2^{19}$ & $\begin{array}{l}{ }^{19} \text { Different between the current method and the concrete } \\
\text { recycling method }\end{array}$ \\
\hline Labor & $45.8^{20}$ & & ${ }^{20} 1$ person at $\$ a b o u t 45,760$ per person per year \\
\hline Fuel & 9.8 & & \\
\hline Fixed overhead & 40.6 & & \\
\hline \multicolumn{4}{|l|}{ Secondary crushing } \\
\hline Equipment & $168.0^{21}$ & & ${ }^{21}$ Secondary crusher equipment cost is about $\$ 1,680,000$ \\
\hline Working capital & $19.3^{22}$ & & $\begin{array}{l}{ }^{22} 15 \% \text { of variable operating cost of } \\
\text { about } \$ 19,260 \text { per unit per year (secondary crusher) }\end{array}$ \\
\hline Equipment maintenance & 32.2 & $10.1^{23}$ & $\begin{array}{l}{ }^{23} \text { Different between the current method and the concrete } \\
\text { recycling method }\end{array}$ \\
\hline Labor & $45.8^{24}$ & & ${ }^{24} 1$ person at about $\$ 45,760$ per person per year \\
\hline Fuel & 9.9 & & \\
\hline Fixed overhead & 40.6 & & \\
\hline
\end{tabular}




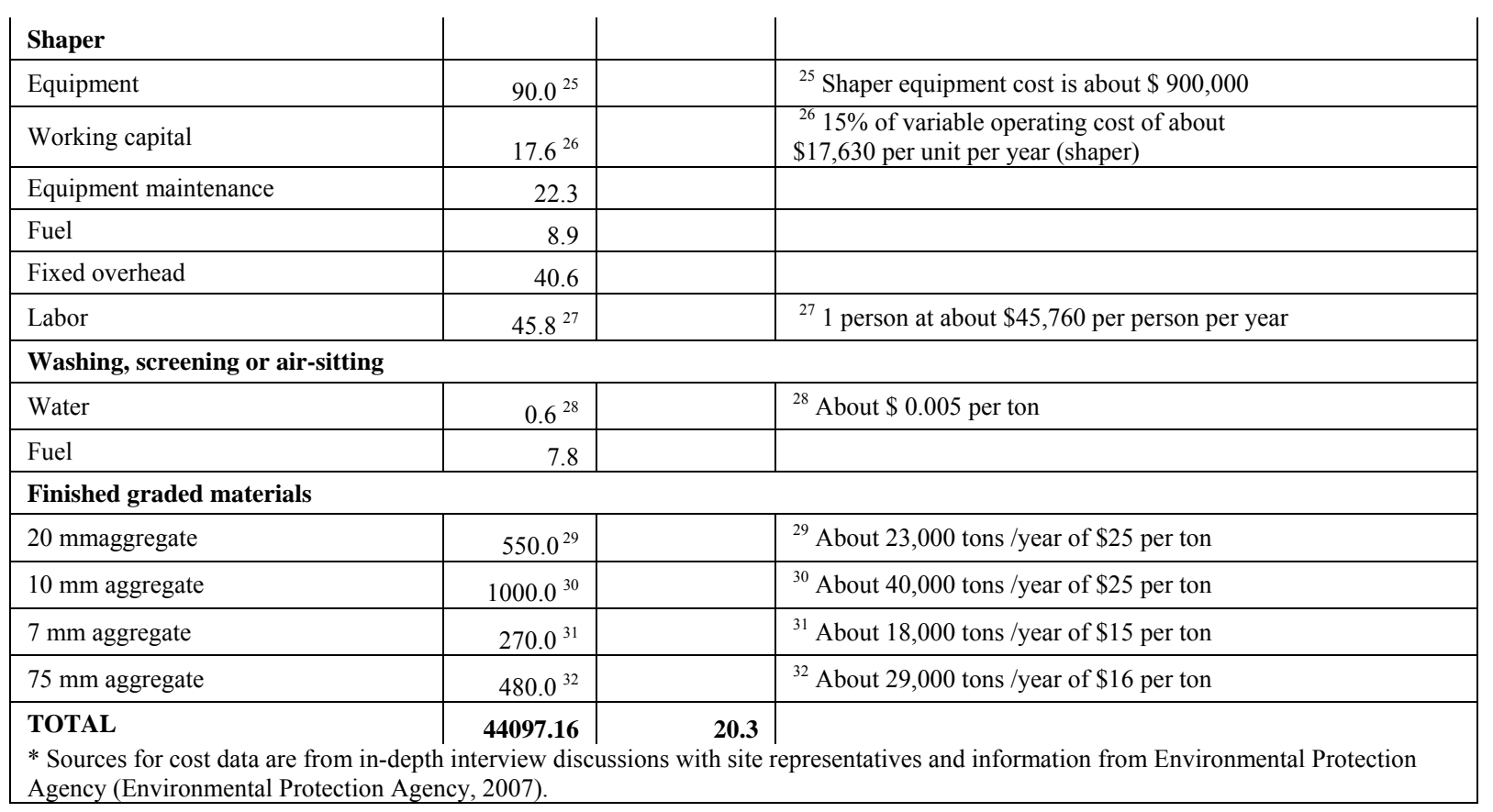


Table 2: Cost and benefit analysis for the concrete recycling method

\begin{tabular}{|c|c|c|c|}
\hline & $\begin{array}{c}\text { Cost } \\
(\$ 1,000 / y r)\end{array}$ & $\begin{array}{c}\text { Benefits } \\
(\$ 1,000 / y r)\end{array}$ & Note* \\
\hline \multicolumn{4}{|l|}{ Construction waste } \\
\hline $\begin{array}{l}\text { Dumping charge from recycling } \\
\text { plants }\end{array}$ & $2914.6^{1}$ & & ${ }^{1}$ About $\$ 25.30$ per ton \\
\hline Landfill dumping charge & & $6566.4^{2}$ & ${ }^{2}$ About $\$ 57$ per ton \\
\hline $\begin{array}{l}\text { Landfill space saved by not dumping } \\
\text { waste }\end{array}$ & & $18777.6^{3}$ & ${ }^{3}$ About $(\$ 220-\$ 57)$ per ton \\
\hline Transportation & & $576.0^{4}$ & ${ }^{4}$ About $\$ 5$ per ton \\
\hline Air pollution & & $3136.3^{5}$ & ${ }^{5}$ About $16.5 \%$ of landfill space charge \\
\hline Gas emission & & $3267.3^{6}$ & ${ }^{6}$ About $17.4 \%$ of landfill space charge \\
\hline Energy consumption & & $4318.9^{7}$ & ${ }^{7}$ About $23 \%$ of landfill space charge \\
\hline Noise pollution & & $3323.6^{8}$ & ${ }^{8}$ About $17.7 \%$ of landfill space charge \\
\hline \multicolumn{4}{|l|}{ Stockpiling } \\
\hline Labor & $37.4^{9}$ & & ${ }^{9} 1$ person at about $\$ 37,440$ per year \\
\hline \multicolumn{4}{|l|}{ Sorting process } \\
\hline Capital & $168.4^{10}$ & & ${ }^{10}$ Pulveriser equipment cost is about $\$ 1,684,000$ \\
\hline Working capital & $19.4^{11}$ & & $\begin{array}{l}11 \text { 15\% variable operating cost at } \\
\text { about } \$ 19390 \text { per unit per year (pulveriser equipment) }\end{array}$ \\
\hline Equipment maintenance & 35.2 & & \\
\hline Labor & $45.8^{12}$ & & ${ }^{12} 1$ person at about $\$ 45,760$ per year \\
\hline Fuel & 7.8 & & \\
\hline Fixed overhead & 40.6 & & \\
\hline \multicolumn{4}{|l|}{ Excavation } \\
\hline Equipment & $156.2^{13}$ & & ${ }^{13}$ Excavator equipment cost is about $\$ 1,562,000$ \\
\hline Working capital & $19.4^{14}$ & & $\begin{array}{l}{ }^{14} 15 \% \text { variable operating cost at } \\
\text { about } \$ 19350 \text { per unit per year ( excavator equipment) }\end{array}$ \\
\hline Equipment maintenance & 34.9 & & \\
\hline Labor & $45.8^{15}$ & & ${ }^{15} 1$ person at about $\$ 45,760$ per year \\
\hline Fuel & 7.8 & & \\
\hline Fixed overhead & 40.6 & & \\
\hline \multicolumn{4}{|l|}{ Crushing process } \\
\hline \multicolumn{4}{|l|}{ Primary crushing } \\
\hline Equipment & $163.2^{16}$ & & ${ }^{16}$ Primary crusher equipment cost is about $\$ 1,632,000$ \\
\hline Working capital & $20.5^{17}$ & & $\begin{array}{l}{ }^{17} 15 \% \text { of variable operating cost of } \\
\text { about } \$ 20,450 \text { per unit per year (primary crusher) }\end{array}$ \\
\hline Equipment maintenance & 40.2 & & \\
\hline Labor & $45.8^{18}$ & & ${ }^{18} 1$ person at about $\$ 45,760$ per year \\
\hline Fuel & 9.8 & & \\
\hline Fixed overhead & 40.6 & & \\
\hline \multicolumn{4}{|l|}{ Magnetic separation } \\
\hline Equipment & $120.8^{19}$ & & ${ }^{19}$ Magnetic Seperator equipment cost is about $\$ 1,207,900$ \\
\hline Working capital & $16.6^{20}$ & & $\begin{array}{l}{ }^{20} 15 \% \text { of variable operating cost of } \\
\text { about } \$ 16640 \text { per unit per year (magnetic seperator) }\end{array}$ \\
\hline Equipment maintenance & 15.9 & & \\
\hline Labor & $45.9^{21}$ & & ${ }^{21} 1$ person at about $\$ 45,760$ per year \\
\hline Fuel & 8.7 & & \\
\hline Fixed overhead & 40.6 & & \\
\hline $\begin{array}{l}\text { Revenue from selling scrap (mainly } \\
\text { steel) }\end{array}$ & & $187.2^{22}$ & ${ }^{22} 1872$ tons per year of about $\$ 100$ per ton \\
\hline \multicolumn{4}{|l|}{ Secondary crushing } \\
\hline Equipment & $166.6^{23}$ & & ${ }^{23}$ Secondary crusher equipment cost is about $\$ 1,666,000$ \\
\hline
\end{tabular}




\begin{tabular}{|c|c|c|c|}
\hline Working capital & $20.8^{24}$ & & $\begin{array}{l}{ }^{24} 15 \% \text { of variable operating cost at } \\
\text { about } \$ 20,780 \text { per unit per year (secondary crusher) }\end{array}$ \\
\hline Equipment maintenance & 42.3 & & \\
\hline Labor & $45.8^{25}$ & & ${ }^{25} 1$ person at about $\$ 45,760$ per year \\
\hline Fuel & 9.9 & & \\
\hline Fixed overhead & 40.6 & & \\
\hline \multicolumn{4}{|l|}{$\begin{array}{l}\text { Manual removal of remaining } \\
\text { contaminants }\end{array}$} \\
\hline Labor & $37.4^{26}$ & & ${ }^{26} 1$ person at about $\$ 37,440$ per year \\
\hline $\begin{array}{l}\text { Removal of large pieces of wood, } \\
\text { paper, plastics etc to landfill }\end{array}$ & $190.0^{27}$ & & ${ }^{27}$ About 3328 ton per year of about $\$ 57$ per ton \\
\hline \multicolumn{4}{|l|}{ Washing, screening or air-sitting } \\
\hline Water & $0.6^{28}$ & & ${ }^{28}$ About $\$ 0.005$ per ton \\
\hline Fuel & 7.8 & & \\
\hline \multicolumn{4}{|l|}{ Finished graded materials } \\
\hline $20 \mathrm{~mm}$ aggregate & $506.0^{29}$ & $45^{33}$ & ${ }^{29}$ About 23,000 tons /year of $\$ 22$ per ton \\
\hline $10 \mathrm{~mm}$ aggregate & $800.0^{30}$ & $200^{33}$ & ${ }^{30}$ About 40,000 tons /year of about $\$ 20$ per ton \\
\hline $7 \mathrm{~mm}$ aggregate & $266.4^{31}$ & $3.6^{33}$ & ${ }^{31}$ About 18,000 tons /year of about $\$ 14.8$ per ton \\
\hline \multirow[t]{2}{*}{$75 \mathrm{~mm}$ rubble } & $462.0^{32}$ & $33.4^{33}$ & ${ }^{32}$ About 30,000 tons $/$ year of about $\$ 15.4$ per ton \\
\hline & & & $\begin{array}{l}{ }^{33} \text { Difference between the current method and the recycling } \\
\text { method }\end{array}$ \\
\hline TOTAL & $6,738.06$ & $37,654.61$ & \\
\hline
\end{tabular}


Table 3: Comparison of the current method and the concrete recycling method

\begin{tabular}{|c|c|c|}
\hline & $\begin{array}{c}\text { The current method } \\
(\$ 1,000 / \text { year })\end{array}$ & $\begin{array}{c}\text { The concrete recycling } \\
\text { method }(\$ 1,000 / \text { year })\end{array}$ \\
\hline Total cost & $44,097.16$ & $6,738.06$ \\
\hline Total benefit & 20.30 & $37,654.61$ \\
\hline Net benefit & $-44,076.84$ & $+30,916.55$ \\
\hline
\end{tabular}




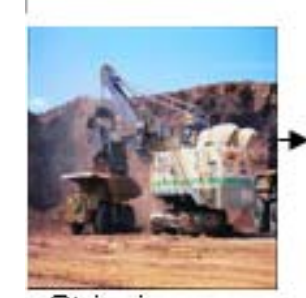

Stripping

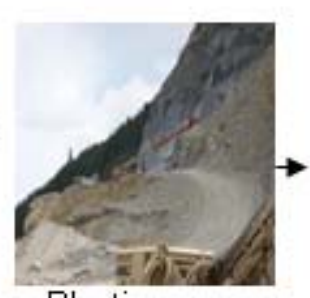

Blasting

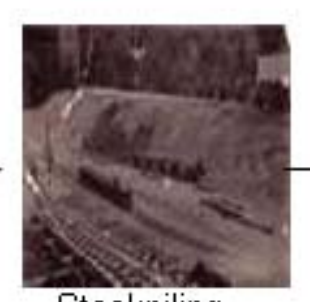

Stockpiling

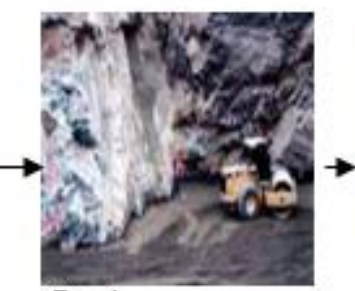

Sorting process

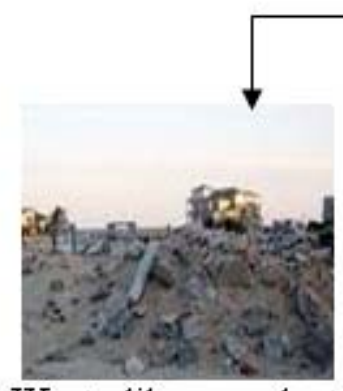

Waste like wood, etc

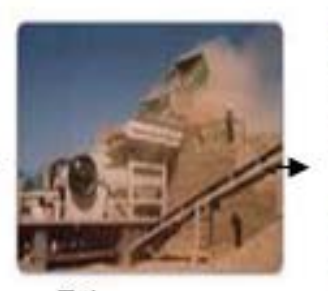

Primary

Crushing
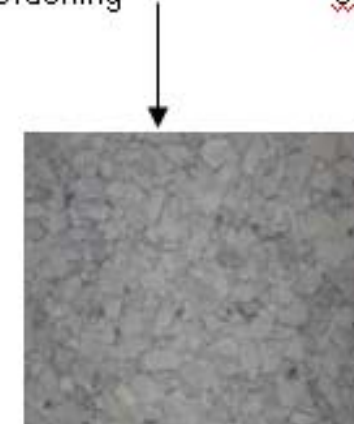

Final Aggregates

$(7,10,20,75 \mathrm{~mm}$ aggregate $)$

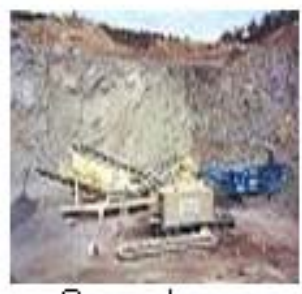

Secondary

Crushing.

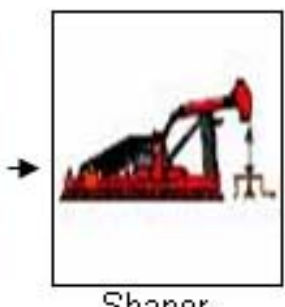

Shaper
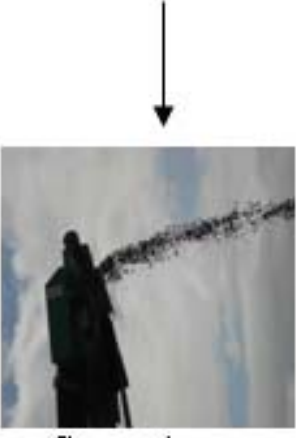

Screening

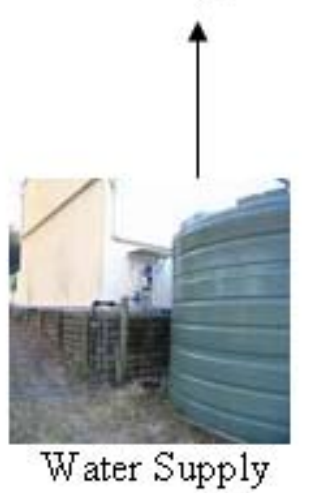

Figure 1: Flow chart of the current method 


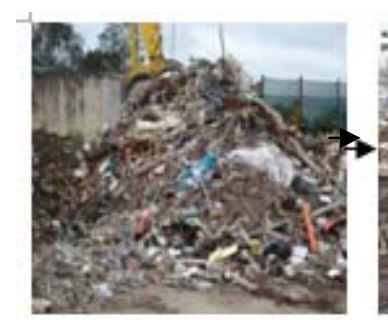

Construction waste

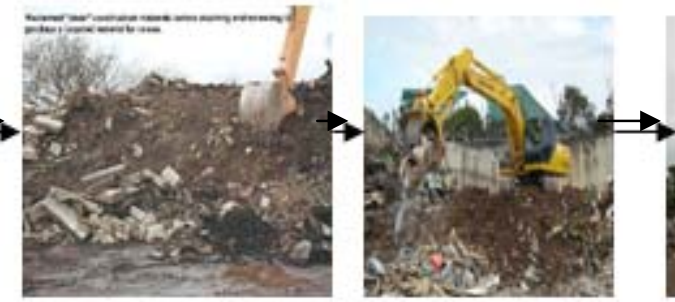

Stockpiling
Sorting process

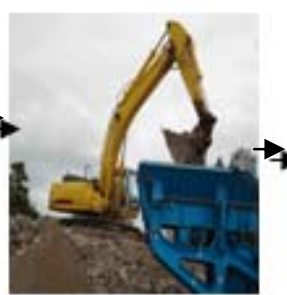

Excavation

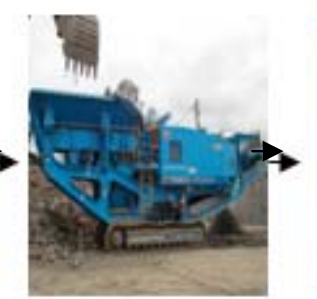

Primary Crushing

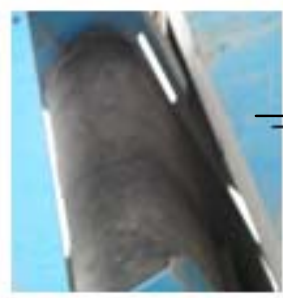

Magnetic Separator

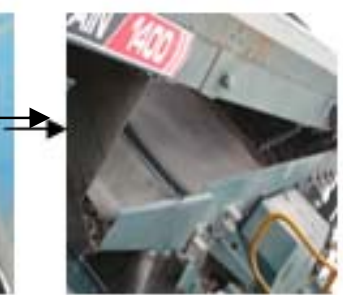

Secondary Crushing

$\downarrow$

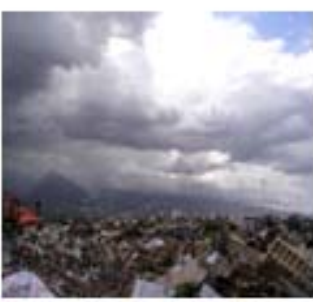

Landfill

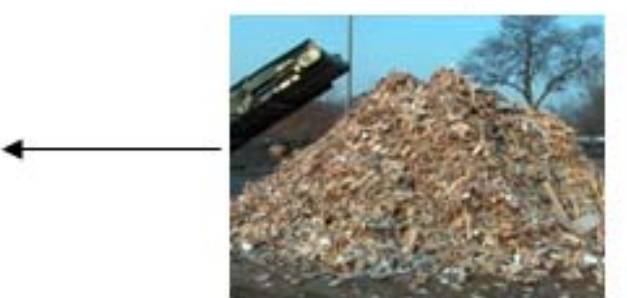

Waste includes Wood and paper

\section{$\uparrow$}
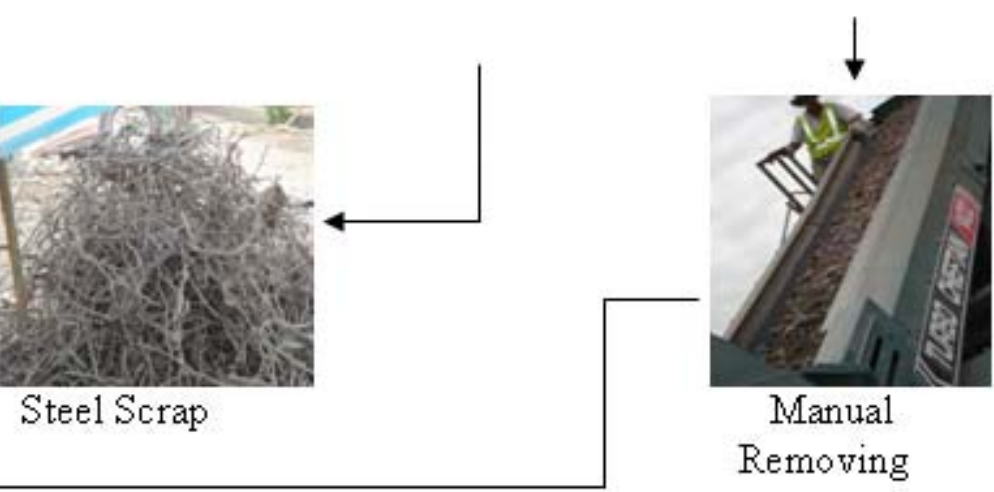

Manual Removing

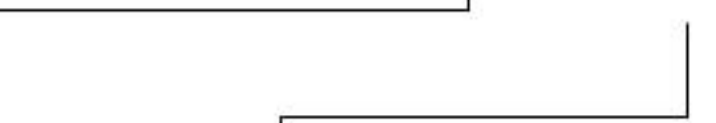

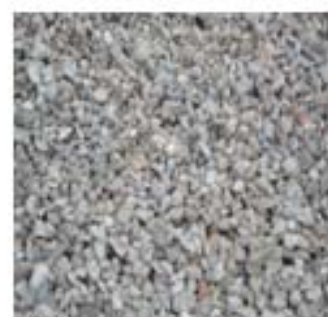

Final aggregates

(7, 10,20 mm aggregate

$75 \mathrm{~mm}$ rubble

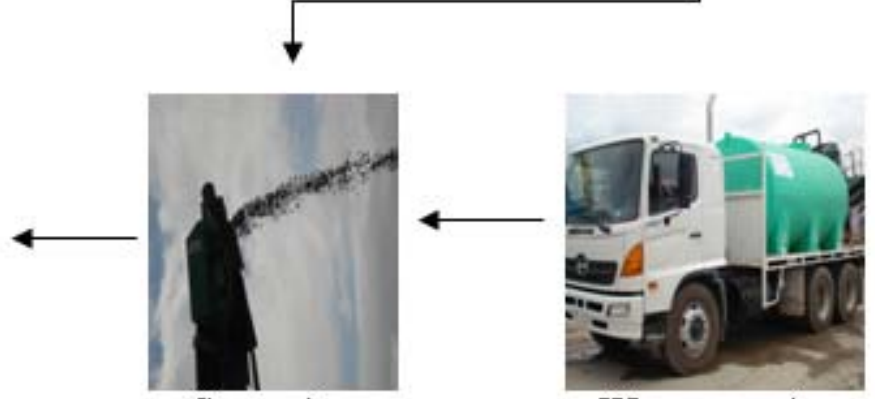

Screening

Water supply

Figure 2: Flow chart of the concrete recycling method 